\title{
Development and Validation of Spectrophotometric Methods for the Simultaneous Determination of Mebeverine Hydrochloride and Chlordiazepoxide in Bulk and in Dosage Form
}

Othman $\mathrm{AA}^{1 *}$, El-Bagary $\mathrm{RI}^{2}$, Elkady $\mathrm{EF}^{2}$ and El-Kerdawy $\mathrm{MM}^{3}$

${ }^{1}$ Medicinal Chemistry Department, Faculty of Pharmacy, Mansoura University, Mansoura 35516, Egypt

${ }^{2}$ Pharmaceutical Chemistry Department, Faculty of Pharmacy, Cairo University, Cairo 11562, Egypt

${ }^{3}$ Central Administration for Pharmaceutical Affairs, Manyal, Cairo 11562, Egypt

*Corresponding author: Othman AA, Medicinal Chemistry Department, Faculty of Pharmacy, Mansoura University, Mansoura 35516, Egypt; Tel: +201224314304, +201000637770; E-mail: a.osman88@yahoo.com

Received date: June 30, 2016; Accepted date: July 03, 2016; Published date: July 06, 2016

Copyright: $\odot 2016$ Othman AA, et al. This is an open-access article distributed under the terms of the Creative Commons Attribution License, which permits unrestricted use, distribution, and reproduction in any medium, provided the original author and source are credited.

\begin{abstract}
Two accurate, precise and simple spectrophotometric methods had been developed and validated for the determination of mebeverine hydrochloride (MEB) and chlordiazepoxide (CHL). The first method was used for the determination of MEB in the range of $5-81 \mu \mathrm{g} / \mathrm{mL}$ and $\mathrm{CHL}$ in the range of $0.5-4 \mu \mathrm{g} / \mathrm{mL}$, MEB was determined by second derivative spectrophotometric determination by measuring the peak amplitude at $234.8 \mathrm{~nm}$ (zero value of $\mathrm{CHL}$ ) whereas $\mathrm{CHL}$ was determined by first derivative spectrophotometric method by measuring the peak amplitude at $280.4 \mathrm{~nm}$ (zero value of MEB). In the second method, three chemometric methods were evaluated for simultaneous assay of MEB and CHL. The developed methods were successfully applied to the analysis of the cited drugs in laboratory prepared mixtures and tablets with good recoveries. The validity of the proposed methods was further assessed by applying the standard addition technique. The validation was carried out following the International Conference on Harmonization (ICH) guidelines.
\end{abstract}

Keywords: Mebeverine Hydrochloride; Chlordiazepoxide; Derivative spectrometry; Chemometrics techniques

\section{Introduction}

Mebeverine hydrochloride is 3,4-dimethoxybenzoic acid 4-[ethyl[2(4-methoxy phenyl)-1-methylethyl]amino]-butylester hydrochloride (Figure 1). It is the most prescribed product currently available for the treatment of irritable bowel syndrome (IBS). It acts as a musculotropic antispasmodic agent with a direct action on the smooth muscle of the gastrointestinal tract especially of the colon, revealing spasm without affecting normal gut motility, and possessing no atropine like action [1-3].<smiles>CCN(CCCCOC(=O)c1ccc(OC)c(OC)c1)C(C)Cc1ccc(OC)cc1</smiles>

Figure 1: Chemical structure of mebeverine hydrochloride.

Chlordiazepoxide is 7-chloro-N-methyl-5-phenyl-3H-1,4benzodiazepine-2-amine 4-oxide (Figure 2). It is a benzodiazepine mainly used in IBS to enhance the effect of the neurotransmitter gamma-amino butyric acid (GABA) at the GABAA receptor, resulting in sedative, hypnotic (sleep-inducing), anxiolytic (anti-anxiety), anticonvulsant and muscle relaxant properties [4].<smiles>CNC1=Nc2ccc(Cl)cc2C(c2ccccc2)=[N+]([O-])C1</smiles>

Figure 2: Chemical structure of chlordiazepoxide.

A literature survey has revealed several analytical methods for the determination of MEB in pharmaceutical dosage form, including spectrophotometry [5-9] conductometry, spectroscopy [10] and liquid chromatography [11-20]. Only few spectrophotometric methods have been reported for the simultaneous estimation of MEB and CHL in capsules in different pH's [21-22], and in tablet form using simultaneous equations and by Q-analysis method has been developed [23]. Univariate spectrophotometric methods via different manipulation pathways [24] has been reported for the simultaneous determination of MEB and CHL. Besides, MEB and CHL has been determined by HPLC [25-29]. 
Citation: Othman AA, El-Bagary RI, Elkady EF, El-Kerdawy MM (2016) Development and Validation of Spectrophotometric Methods for the Simultaneous Determination of Mebeverine Hydrochloride and Chlordiazepoxide in Bulk and in Dosage Form. Pharm Anal Acta 7: 501. doi: $10.4172 / 2153-2435.1000501$

Page 2 of 8

A literature survey has revealed several analytical methods for the determination of CHL either alone or in mixtures with other drugs $[30-40]$.

Thus the aim of the present work is to develop and validate simple, rapid and inexpensive analytical methods using the derivative spectrophotometry and chemometric techniques for the simultaneous determination of MEB and CHL to be applied to their determination in pharmaceutical preparation as a substitute for the published methods for the cited mixture.

Derivative spectrophotometry is an analytical technique of great utility for extracting of both qualitative and quantitative information from spectra composed of unresolved bands and for eliminating effect of baseline shifts. It also allows fast resolution of multicomponent mixture of drugs [41]. Alternatively, in recent years multivariate calibrations, such as Classical Least Squares (CLS), Principal Component Regression (PCR), and Partial Least Squares (PLS) started to be applied to the analysis of the analytical data obtained in all the instrumentations. The same methods have been applied to the simultaneous spectrophotometric determination of drugs in pharmaceutical formulations containing two or more compounds with overlapping spectra $[42,43]$. Besides, the chemometric calibration methods have been used extensively in quantitative spectral analysis to get selective information from unselective data.

\section{Experimental}

\section{Instrumentation}

A Shimadzu 1800 double beam ultraviolet/visible spectrometer, Japan connected to an IBM compatible computer with $1 \mathrm{~cm}$ quartz cell supported with UV probe software was used.

\section{Reagents and reference samples}

Pharmaceutical grade MEB, certified to contain $99.80 \%$, pharmaceutical grade CHL, certified to contain $99.80 \%$. Coloverin A tablets nominally containing $135 \mathrm{mg}$ MEB and $5 \mathrm{mg}$ CHL per tablet were supplied from Chemipharm, Egypt. Methanol HPLC grade was purchased from Fisher Scientific, UK.

\section{Preparation of standard and working solutions}

Preparation of MEB standard stock solution: Accurately weight 25 mg MEB was transferred into a $25 \mathrm{~mL}$ volumetric flask and dissolved in and completed to the mark with methanol $(1 \mathrm{mg} / \mathrm{mL})$.

Preparation of MEB working solution: Five microliters of MEB stock solution were transferred into a $50 \mathrm{~mL}$ volumetric flask; the volume was completed to mark with methanol $(100 \mu \mathrm{g} / \mathrm{mL})$.

Preparation of CHL stock solution: Accurately weight $25 \mathrm{mg}$ of CHL were transferred into a $25 \mathrm{~mL}$ volumetric flask and dissolved in and completed to volume with methanol $(1 \mathrm{mg} / \mathrm{mL})$.

Preparation of CHL working solution: Five microliters of CHL stock solution were transferred to a $50 \mathrm{~mL}$ volumetric flask and completed to mark with methanol $(100 \mu \mathrm{g} / \mathrm{mL})$, and $5 \mathrm{~mL}$ of this solution were transferred into a $50 \mathrm{~mL}$ volumetric flask; the volume was completed to mark with methanol $(10 \mu \mathrm{g} / \mathrm{mL})$.

\section{Procedure}

Method I (Derivative spectrophotometric method) Construction of calibration curves: Different aliquots from MEB and CHL working solutions were transferred into two series of $10 \mathrm{~mL}$ volumetric flasks, the volumes were completed with methanol to give final concentrations of $5-81 \mu \mathrm{g} / \mathrm{mL}$ and $0.5-4 \mu \mathrm{g} / \mathrm{mL}$ for MEB and CHL, respectively.

The absorbance spectra of each solution was recorded against methanol as a blank in the range $200-400 \mathrm{~nm}$, and then the second derivative spectra, and the first derivative for $\mathrm{MEB}$ and $\mathrm{CHL}$ respectively using $\Delta \lambda=4$ and a scaling factor $=50$ was computed. The amplitudes at $234.8 \mathrm{~nm}$ and $280.4 \mathrm{~nm}$ for MEB and CHL, respectively, were measured and then plotted against corresponding concentrations to obtain calibration graphs and the regression equations.

Method II (Chemometric method) Construction of Training set: Twelve binary mixtures of MEB and CHL were prepared by placing different volumes of their working solutions into series of $10 \mathrm{~mL}$ volumetric flasks the volumes were completed with methanol in table (1). The absorbances of these mixtures were measured between 260 and $310 \mathrm{~nm}$ at $0.2 \mathrm{~nm}$ intervals against methanol as a blank.

Construction of CLS, PCR, and PLS models: Three multivariate calibration models (CLS, PCR and PLS) were constructed using the data obtained. In these methods the absorbance data matrix for training set concentration matrix was obtained by measuring the absorbances between 260 and $310 \mathrm{~nm}$ at $0.2 \mathrm{~nm}$ intervals. Calibration or regression was then obtained by using the absorbance data matrix and the concentration data matrix for the determination of the unknown concentration of MEB/CHL in their binary mixtures and pharmaceutical dosage forms. For the CLS method, the model was constructed with non-zero intercept.

The computer was fed with the absorbance and concentration matrices of the training set and calculations were made to obtain the $\mathrm{K}$ matrix (i.e., absorptivity at different wavelength). For the PCR and PLS methods, the training set absorbance and concentration matrices together with PLS-toolbox 2.0 software were used for calculations.

Selection of the optimum number of factors to build the PCR and PLS models: In order to select the optimum number of factors, crossvalidation method was used leaving out one sample at a time [44]. Given a set of 12 calibration spectra for MEB/CHL mixture, the PCR and PLS calibrations were performed and using this calibration the concentration of the sample left out was predicted. This process was repeated until each sample had been left out once.

The predicted concentrations of the components in each sample were compared with the actual concentrations in this calibration samples and Root-Mean-Square Error of Cross-Validation (RMSECV) was calculated for each method. It indicates both of the precision and accuracy of predictions. Visual inspection was used for deciding the optimum number of factors.

$$
R M S E C V=\sqrt{\frac{P R E S S}{n}}(1)
$$

Where PRESS is the predicted residual error sum of squares and $n$ is the number of calibration samples [45].

$$
\text { PRESS }=\sum\left(Y_{\text {pred }}-Y_{\text {true }}\right)^{2}(2)
$$

Where $\mathrm{Y}$ pred and $\mathrm{Y}$ true are predicted and true concentrations in $\mu \mathrm{g} / \mathrm{mL}$, respectively 
Citation: Othman AA, El-Bagary RI, Elkady EF, El-Kerdawy MM (2016) Development and Validation of Spectrophotometric Methods for the Simultaneous Determination of Mebeverine Hydrochloride and Chlordiazepoxide in Bulk and in Dosage Form. Pharm Anal Acta 7: 501. doi: $10.4172 / 2153-2435.1000501$

Page 3 of 8

\begin{tabular}{|l|l|l|}
\hline \multirow{2}{*}{ Sample No. } & \multicolumn{2}{|l|}{ Claimed conc. $(\mathrm{mg} / \mathrm{mL})$} \\
\cline { 2 - 3 } & MEB & CHL \\
\hline 1 & 27 & 0.8 \\
\hline 2 & 27 & 1 \\
\hline 3 & 27 & 1.2 \\
\hline 4 & 35.1 & 1.1 \\
\hline 5 & 35.1 & 1.3 \\
\hline 6 & 35.1 & 1.5 \\
\hline 7 & 51.3 & 1.7 \\
\hline 8 & 51.3 & 1.9 \\
\hline 9 & 51.3 & 2.1 \\
\hline 10 & 59.4 & 2 \\
\hline
\end{tabular}

\begin{tabular}{|l|l|l|}
\hline 11 & 59.4 & 2.2 \\
\hline 12 & 59.4 & 2.4 \\
\hline
\end{tabular}

Table 1: The concentrations of different mixtures of MEB and CHL used in the training set.

\section{Assay of laboratory-prepared mixtures}

Method I: For validation of derivative method, aliquots of MEB and CHL working solutions were accurately transferred into a series of 10 $\mathrm{mL}$ volumetric flasks to give final concentrations $18.9-51.3 \mu \mathrm{g} / \mathrm{mL}$ for MEB and $0.7-1.9 \mu \mathrm{g} / \mathrm{mL}$ for CHL as shown in Table 2.

The absorption spectrum was recorded for the laboratory prepared mixtures against methanol as a blank. The amplitudes of the second derivative spectra and first derivative spectra were measured at 234.8 $\mathrm{nm}$ for MEB and $280.4 \mathrm{~nm}$ for CHL, respectively. The concentrations of MEB and CHL were calculated from their corresponding regression equations.

\begin{tabular}{|c|c|c|c|c|c|}
\hline \multicolumn{2}{|c|}{ Amount taken $(\mu \mathrm{g} / \mathrm{mL})$} & \multicolumn{2}{|l|}{ MEB } & \multicolumn{2}{|l|}{$\mathrm{CHL}$} \\
\hline MEB & $\mathrm{CHL}$ & Amount found $(\mu \mathrm{g} / \mathrm{mL})$ & $\%$ Recovery & Amount found $(\mu \mathrm{g} / \mathrm{mL})$ & $\%$ Recovery \\
\hline 18.9 & 0.7 & 18.9313 & 100.165 & 0.6926 & 98.94 \\
\hline 21.6 & 0.8 & 21.6069 & 100.032 & 0.8055 & 100.69 \\
\hline 24.3 & 0.9 & 24.1346 & 99.319 & 0.8964 & 99.596 \\
\hline 29 & 1.1 & 29.0792 & 100.273 & 1.1117 & 101.06 \\
\hline 35.1 & 1.3 & 34.9918 & 99.692 & 1.3002 & 100.02 \\
\hline 45 & 1.6 & 44.962 & 99.916 & 1.591 & 99.45 \\
\hline 45.9 & 1.7 & 45.8785 & 99.953 & 1.6956 & 99.742 \\
\hline 51.3 & 1.9 & 51.0599 & 99.532 & 1.92378 & 101.251 \\
\hline Mean & - & - & 99.86025 & - & 100.0936 \\
\hline \pm S.D. & - & - & 0.323696 & - & 0.823829 \\
\hline \%R.S.D & - & - & 0.324 & - & 0.823 \\
\hline
\end{tabular}

Table 2: Results for the determination of the studied drugs in their laboratory prepared mixtures by Method I.

Method II: For validation of the PCR, PLS and CLS models, the concentrations of MEB and CHL in the validation set were predicted by using the proposed PCR, PLS and CLS models. To evaluate the prediction performance of the proposed chemometric models, a set of 9 synthetic validation mixtures were prepared as shown in table 3 , and submitted for prediction by each of the calibration models.

\begin{tabular}{|l|l|l|l|l|l|l|l|}
\hline \multicolumn{2}{|l|}{$\begin{array}{l}\text { Concentration } \\
(\boldsymbol{\mu} \mathrm{g} / \mathrm{mL})\end{array}$} & \multicolumn{3}{l|}{ \%Recovery MEB } & \multicolumn{3}{l|}{$\%$ Recovery CHL } \\
\hline MEB & CHL & CLS & PCR & PLS & CLS & PCR & PLS \\
\hline 32.4 & 1.2 & 99.42 & 98.60 & 98.52 & 102.58 & 101.22 & 101.57 \\
\hline 32.4 & 1.4 & 99.41 & 98.64 & 98.55 & 101.30 & 99.85 & 99.77 \\
\hline 37.8 & 1.2 & 100.47 & 100.0 & 100.10 & 102.66 & 102.12 & 101.98 \\
\hline 37.8 & 1.4 & 100.74 & 100.23 & 100.27 & 101.04 & 100.16 & 99.84 \\
\hline
\end{tabular}

\begin{tabular}{|l|l|l|l|l|l|l|l|}
\hline 37.8 & 1.6 & 101.20 & 100.36 & 100.17 & 102.02 & 100.57 & 101.12 \\
\hline 43.2 & 1.6 & 100.81 & 100.14 & 99.97 & 102.58 & 101.58 & 102.61 \\
\hline 48.6 & 1.6 & 100.18 & 99.73 & 99.73 & 102.46 & 101.92 & 102.26 \\
\hline 48.6 & 1.8 & 101.18 & 100.61 & 100.48 & 100.32 & 99.49 & 100.33 \\
\hline 48.6 & 2.0 & 100.68 & 100.07 & 99.85 & 101.44 & 100.36 & 101.18 \\
\hline Mean & - & 100.45 & 99.82 & 99.74 & 101.82 & 100.81 & 101.18 \\
\hline \pm S.D. & - & 0.668 & 0.722 & 0.717 & 0.835 & 0.939 & 1.032 \\
\hline \%R.S.D. & - & 0.67 & 0.72 & 0.72 & 0.82 & 0.93 & 1.02 \\
\hline
\end{tabular}

Table 3: Results obtained for determination of MEB and CHL in synthetic mixtures using CLS, PCR, and PLS techniques by Method II. 
Citation: Othman AA, El-Bagary RI, Elkady EF, El-Kerdawy MM (2016) Development and Validation of Spectrophotometric Methods for the Simultaneous Determination of Mebeverine Hydrochloride and Chlordiazepoxide in Bulk and in Dosage Form. Pharm Anal Acta 7: 501. doi: $10.4172 / 2153-2435.1000501$

Page 4 of 8

\section{Sample solution preparation}

For method I and II, twenty Coloverin A tablets were accurately weighted, crushed and mixed well. Accurate weight of the powder tablets equivalent to $50 \mathrm{mg} \mathrm{MEB}$ and $1.85 \mathrm{mg}$ CHL was transferred into a $50 \mathrm{~mL}$ volumetric flask to which about $30 \mathrm{~mL}$ methanol were then added. The solution was sonicated for $15 \mathrm{~min}$ with intermediate shaking. Finally, the volume was completed to the mark with methanol. The solution was filtered discarding first $10 \mathrm{~mL}$ and the filtrate was used as the sample solution.

\section{Results and Discussions}

\section{Method development}

Method I: The zero order spectra of MEB and CHL in methanol showed severe overlap that prevents the use of direct spectrophotometry for their analysis without preliminary separation (Figure 3). Derivative spectrophotometry is a well-established technique for the assay of drugs in mixtures and in pharmaceutical dosage forms enhancing the resolution of overlapping bands.

It can be applied for the determination of a drug in the presence of another by selecting a wavelength where contribution of one compound is almost zero while the compound to be determined has a reasonable value, so it has been used in the determination of many drugs [46]. By using the trough amplitudes of second derivative spectrum of MEB at $234.8 \mathrm{~nm}$ where CHL showed zero crossing , and the trough amplitudes of first derivative of $\mathrm{CHL}$ at $280.4 \mathrm{~nm}$, where MEB showed zero crossing (Figure 4) able to resolve such overlapping between MEB and CHL.

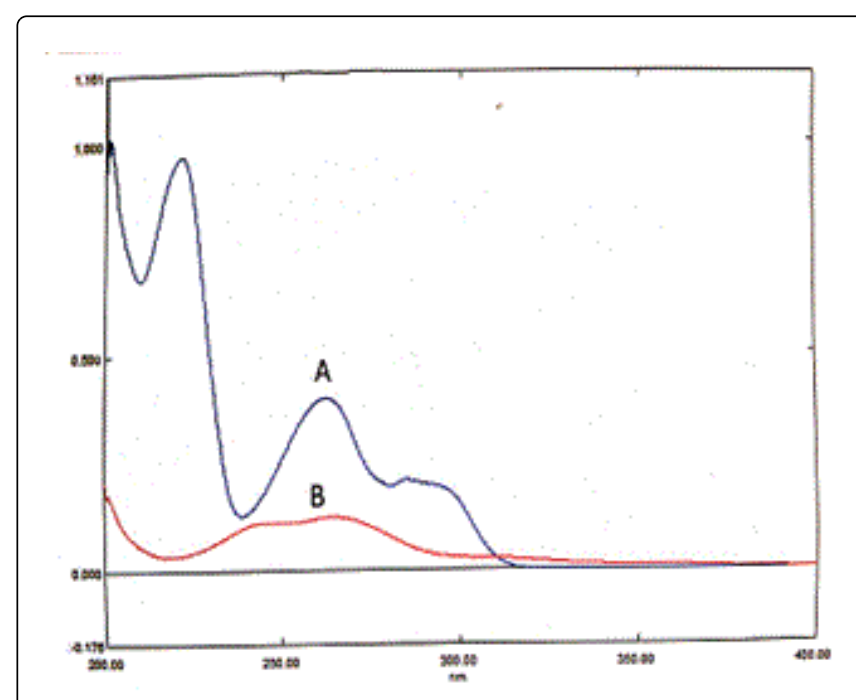

Figure 3: Zero order absorption spectra of MEB $(27 \mu \mathrm{g} / \mathrm{mL})(\mathrm{A})$ and of CHL(1 $\mu \mathrm{g} / \mathrm{mL})(B)$.

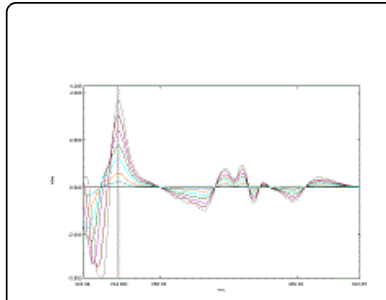

(a)

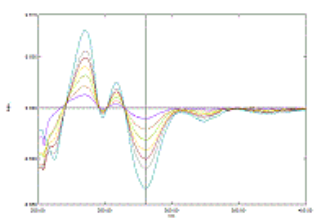

(b)
Figure 4: Second derivative Spectra for Different Concentrations of $\operatorname{MEB}(5,13.5,27,40.5,54,67.5$ and $81 \mu \mathrm{g} / \mathrm{mL}$ ) (a) and First derivative spectra for Different Concentrations of CHL $(0.5,1,1.5,2,2.5,3$ and 4 $\mu \mathrm{g} / \mathrm{mL}$ ) (b) $\Delta \lambda=4$ and a scaling factor $=50$.

The zero crossing wavelengths at $234.8 \mathrm{~nm}$ for $\mathrm{CHL}$ and $280.4 \mathrm{~nm}$ for MEB were selected since reproducible readings were obtained at these wavelengths. A $\delta \lambda$ of 4 and scaling factor of 50 were used for determination of MEB and CHL.

Method II: Three chemometric methods are applied CLS, PCR and PLS for simultaneous determination of the two drugs. The quality of multi component analysis depends on the wavelength range and the spectral mode used [47]. Twelve different concentration mixtures were used as the calibration samples to construct the models, the spectra of these mixtures were collected and examined, the regions from 200-260 $\mathrm{nm}$ and above $310 \mathrm{~nm}$ were rejected, however, the wavelength range $260-310 \mathrm{~nm}$ in the intervals with $\lambda=0.2 \mathrm{~nm}$ was chosen as it provided the greatest amount of information about the mixture components. The ratio of the two drugs in Coloverin A tablets was taken in to consideration during the construction of both training and validation sets. CLS model was constructed with non-zero intercept. The nonzero intercept allows an additional degree of freedom when $\mathrm{k}$ matrix is calculated. This provides an additional opportunity to adjust the effects of the extraneous substances [48].

The CLS method requires all components in the calibration samples to be known. For the PCR and PLS techniques, selection of the optimum number of factors was a very important step before constructing the models. If the number of factors retained was more than the number required, more noise would be added to the data.

On the other hand, if the number retained was less than the number required, meaningful data that could be necessary for the calibration might be ignored. Visual inspection could be used for determining the optimum number of factors. Three factors were found suitable for both PCR and PLS methods and the plot of number of factors against RMSECV as presented in Figures (5) and (6). 
Citation: Othman AA, El-Bagary RI, Elkady EF, El-Kerdawy MM (2016) Development and Validation of Spectrophotometric Methods for the Simultaneous Determination of Mebeverine Hydrochloride and Chlordiazepoxide in Bulk and in Dosage Form. Pharm Anal Acta 7: 501. doi: $10.4172 / 2153-2435.1000501$

Page 5 of 8



(b) CHL PCR

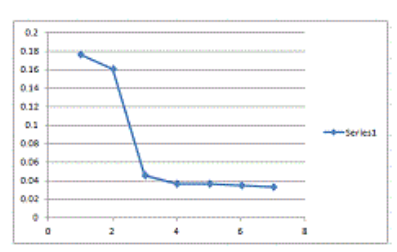

Figure 5: RMSECV plot as a function of the number of principle components used to construct the PCR model (a) MEB and (b) CHL. (a) MEB PLS

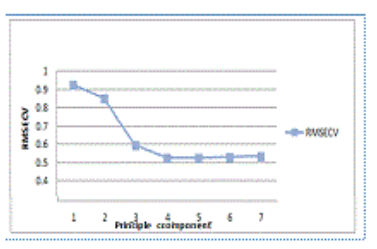

Figure 6: RMSECV plot as a function of the number of principle components used to construct the PLS model (a) MEB and (b) CHL.

\section{Validation of Method I and Method II} [49].

The proposed methods were validated following the ICH guidelines

Linearity: The linearity of the derivative spectrophotometric methods was evaluated by analyzing a series of different concentrations of each drug. In this study, seven concentrations for MEB and CHL, ranging from 5-81 $\mu \mathrm{g} / \mathrm{mL}$ and $0.5-4 \mu \mathrm{g} / \mathrm{mL}$, respectively in methanol were prepared.

Second derivative Spectra for MEB and first derivative spectra for CHL using the peak amplitude at $234.8 \mathrm{~nm}$ for MEB and the peak amplitude at $280.4 \mathrm{~nm}$ for CHL using $\Delta \lambda=4$ and a scaling factor=50, good linearity of the calibration curve was verified by the high correlation coefficient( $r$ ) of the regression equation. The analytical data of the calibration curve including standard deviations for the slope and intercept (Sb, Sa) are summarized in table 4.

\begin{tabular}{|c|c|c|}
\hline Item & MEB & CHL \\
\hline Derivative & $2 n d D$ & $1 \mathrm{stD}$ \\
\hline Wavelength of detection & $234.8 \mathrm{~nm}$ & $280.4 \mathrm{~nm}$ \\
\hline Linearity range & $5-81 \mu \mathrm{g} / \mathrm{mL}$ & $0.5-4 \mu \mathrm{g} / \mathrm{mL}$ \\
\hline Regression equation & $Y=0.0451 x-0.0258$ & $Y=0.1981 \times+0.0031$ \\
\hline Regression coefficient $(r 2)$ & 0.9997 & 0.9999 \\
\hline S.D.of slope (Sa) & 0.01733 & 0.001749 \\
\hline S.D.of intercept (Sb) & 0.000356 & 0.00074 \\
\hline C.I. for the slope & $0.0451 \pm 0.0009$ & $0.1981 \pm 0.001$ \\
\hline C.I. for the intercept & $-0.0258 \pm 0.044$ & $0.0031 \pm 0.004$ \\
\hline LOQ & $0.388 \mu \mathrm{g} / \mathrm{mL}$ & $0.150 \mu \mathrm{g} / \mathrm{mL}$ \\
\hline LOD & $0.128 \mu \mathrm{g} / \mathrm{mL}$ & $0.05 \mu \mathrm{g} / \mathrm{mL}$ \\
\hline $\begin{array}{l}\text { Recovery for standard } \\
\text { added }\end{array}$ & $100.13 \pm 0.935$ & $100.65 \pm 1.257$ \\
\hline $\begin{array}{l}\text { Recovery for } \begin{array}{l}\text { drug in } \\
\text { prepared }\end{array} \\
\text { laboratory } \\
\text { mixtures }\end{array}$ & $99.86 \pm 0.323$ & $100.093 \pm 0.823$ \\
\hline Accuracy & $100.79 \pm 0.64$ & $100.24 \pm 1.11$ \\
\hline $\begin{array}{ll}\text { Intraday } & \text { precision } \\
(\% \text { R.S.D, } n=9) & \end{array}$ & $0.21-0.93$ & $0.21-0.81$ \\
\hline $\begin{array}{ll}\text { Interday } & \text { Precision } \\
(\% \text { R.S.D, } n=9) & \end{array}$ & $0.56-1.12$ & $0.57-1.22$ \\
\hline
\end{tabular}

Table 4: Results obtained by for the determination of MEB and CHL Method I. Sa: standard deviation of intercept, Sb: standard deviation of slope and C.L: confidence limits.

\section{Accuracy}

For method I: The satisfactory recovery percentage results for the assay of MEB with CHL in their laboratory prepared mixtures at different concentration levels within the linear range of each compound (99.86 \pm 0.323 for MEB and 100.093 \pm 0.823 for CHL ),indicate the accuracy of the method as shown in table (2). Also, the standard addition method was applied for the determination of MEB and CHL in Coloverin A tablets revealed good \% recovery of added standard of MEB (100.13 \pm 0.935$)$ and CHL $(100.65 \pm 1.257)$ as shown in table (5) indicating the accuracy of the method in the dosage form by proposed derivative method.

\begin{tabular}{|c|c|c|c|c|c|c|c|c|c|c|c|}
\hline \multicolumn{2}{|c|}{$\begin{array}{l}\text { Amount of tablet } \\
\mu \mathrm{g} / \mathrm{mL}\end{array}$} & \multicolumn{2}{|c|}{$\begin{array}{l}\text { Amount of Added } \\
\mu \mathrm{g} / \mathrm{mL}\end{array}$} & \multicolumn{2}{|r|}{ Tablet MEB } & \multicolumn{2}{|r|}{ Tablet CHL } & \multicolumn{2}{|r|}{ Added MEB } & \multicolumn{2}{|r|}{ Added CHL } \\
\hline MEB & $\mathrm{CHL}$ & MEB & $\mathrm{CHL}$ & $\begin{array}{l}\text { Tablet } \\
\text { Found } \\
\mu \mathrm{g} / \mathrm{mL}\end{array}$ & $\%$ Recovery & $\begin{array}{l}\text { Tablet } \\
\text { found } \\
\mu \mathrm{g} / \mathrm{mL}\end{array}$ & \% Recovery & $\begin{array}{l}\text { Added } \\
\text { found } \\
\mu \mathrm{g} / \mathrm{mL}\end{array}$ & $\%$ Recovery & $\begin{array}{l}\text { Added } \\
\text { found } \\
\mu \mathrm{g} / \mathrm{mL}\end{array}$ & $\%$ Recovery \\
\hline 13.5 & 0.5 & 62.1 & 2.3 & 13.69 & 101.41 & 0.501 & 100.20 & 62.67 & 100.9 & 2.304 & 100.1 \\
\hline 16.2 & 0.6 & 59.4 & 2.2 & 16.12 & 99.51 & 0.597 & 99.50 & 59.68 & 100.4 & 2.203 & 100.1 \\
\hline 21.6 & 0.8 & 51.3 & 1.9 & 22.32 & 103.3 & 0.807 & 100.88 & 50.83 & 99.1 & 1.930 & 101.6 \\
\hline
\end{tabular}


Citation: Othman AA, El-Bagary RI, Elkady EF, El-Kerdawy MM (2016) Development and Validation of Spectrophotometric Methods for the Simultaneous Determination of Mebeverine Hydrochloride and Chlordiazepoxide in Bulk and in Dosage Form. Pharm Anal Acta 7: 501. doi: $10.4172 / 2153-2435.1000501$

Page 6 of 8

\begin{tabular}{|l|l|l|l|l|l|l|l|l|l|l|l|}
\hline 27 & 1.0 & 43.2 & 1.6 & 26.82 & 99.33 & 0.987 & 98.70 & 42.95 & 99.4 & 1.609 & 100.6 \\
\hline 37.8 & 1.4 & 29.7 & 1.1 & 37.82 & 100.05 & 1.389 & 99.21 & 29.38 & 98.9 & 1.131 & 102.8 \\
\hline 43.2 & 1.6 & 24.3 & 0.9 & 43.39 & 100.44 & 1.588 & 99.25 & 24.66 & 101.5 & 0.899 & 99.9 \\
\hline 48.6 & 1.8 & 16.2 & 0.6 & 48.69 & 100.19 & 1.808 & 100.44 & 16.33 & 100.8 & 0.592 & 98.7 \\
\hline 51.3 & 1.9 & 13.5 & 0.5 & 51.23 & 99.86 & 1.909 & 100.47 & 13.50 & 100 & 0.507 & 101.4 \\
\hline Mean & - & - & - & - & 100.515 & - & 99.831 & - & 100.13 & - & 100.65 \\
\hline \pm S.D. & - & - & - & - & 1.294 & - & 0.768 & - & 0.935 & - & 1.257 \\
\hline \%R.S.D. & - & - & - & - & 1.29 & - & 0.77 & - & 0.93 & - & 1.25 \\
\hline
\end{tabular}

Table 5: Results for the determination of MEB and CHL by standard addition method in drug formulation (Coloverin A tablets) by Method I.

For method II: The accuracy was assessed by applying the proposed chemometric methods obtained for the simultaneous determination of $\mathrm{MEB}$ and $\mathrm{CHL}$ as binary mixtures in pure form in concentration ranges of $(32.4-48.6 \mu \mathrm{g} / \mathrm{mL})$ for MEB and $(1.2-2 \mu \mathrm{g} / \mathrm{mL})$ for CHL. The mean percentage recoveries were found $(100.45 \pm 0.668,99.82 \pm 0.722$ and $99.74 \pm 0.717)$ for MEB and $(101.82 \pm 0.835,100.81 \pm 0.939$ and
$101.18 \pm 1.032$ ) for CHL as shown in table (3). Also accuracy of the drug product was confirmed by recovery studies from tablets at different levels of standard additions, the mean percentage recoveries of added were found $(101.04 \pm 1.62,100.28 \pm 1.61$ and $100.08 \pm 1.54)$ for MEB and $(100.94 \pm 1.35,99.46 \pm 0.96$ and $100.98 \pm 1.32)$ for CHL as shown in table (6).

\begin{tabular}{|c|c|c|c|c|c|c|c|c|c|c|c|c|c|c|c|}
\hline \multirow{2}{*}{\multicolumn{2}{|c|}{$\begin{array}{l}\text { Amount of tablet } \\
\mu \mathrm{g} / \mathrm{mL}\end{array}$}} & \multirow{2}{*}{\multicolumn{2}{|c|}{$\begin{array}{l}\text { Amount of Added } \\
\mu \mathrm{g} / \mathrm{mL}\end{array}$}} & \multicolumn{6}{|l|}{ Tablet } & \multicolumn{6}{|l|}{ Added } \\
\hline & & & & \multicolumn{3}{|c|}{ MEB \%Recovery } & \multicolumn{3}{|c|}{ CHL \%Recovery } & \multicolumn{3}{|c|}{ MEB \%Recovery } & \multicolumn{3}{|c|}{ CHL \%Recovery } \\
\hline MEB & $\mathrm{CHL}$ & MEB & $\mathrm{CHL}$ & CLS & PCR & PLS & CLS & PCR & PLS & CLS & PCR & PLS & CLS & PCR & PLS \\
\hline 18.9 & 0.7 & 27 & 1 & 104.71 & 104.36 & $\begin{array}{l}104.5 \\
1\end{array}$ & 103.66 & 103.98 & 102.80 & 99.34 & 99.02 & 99.07 & 99.26 & 99.41 & 99.05 \\
\hline 27 & 1 & 24.3 & 0.9 & 101.86 & 101.53 & $\begin{array}{l}101.7 \\
4\end{array}$ & 102.63 & 102.43 & 100.82 & 100.90 & 100.72 & 100.69 & 101.45 & 101.20 & $\begin{array}{l}101.4 \\
3\end{array}$ \\
\hline 32.4 & 1.2 & 21.6 & 0.8 & 103.60 & 103.16 & $\begin{array}{l}103.2 \\
7\end{array}$ & 103.50 & 103.77 & 102.87 & 99.61 & 98.28 & 98.02 & 102.02 & 98.39 & $\begin{array}{l}100.2 \\
6\end{array}$ \\
\hline 37.8 & 1.4 & 18.9 & 0.7 & 102.15 & 101.72 & $\begin{array}{l}101.8 \\
4\end{array}$ & 100.34 & 100.61 & 99.72 & 101.18 & 99.88 & 99.50 & 102.69 & 98.82 & $\begin{array}{l}101.6 \\
3\end{array}$ \\
\hline 40.5 & 1.5 & 16.2 & 0.6 & 102.84 & 102.56 & $\begin{array}{l}102.7 \\
9\end{array}$ & 98.63 & 99.01 & 97.26 & 103.89 & 102.87 & 102.42 & 100.63 & 99.33 & $\begin{array}{l}102.9 \\
3\end{array}$ \\
\hline 43.2 & 1.6 & 13.5 & 0.5 & 102.3 & 101.81 & $\begin{array}{l}101.8 \\
6\end{array}$ & 95.22 & 95.54 & 95.23 & 101.34 & 100.90 & 100.78 & 99.61 & 99.60 & $\begin{array}{l}100.5 \\
8\end{array}$ \\
\hline \multicolumn{4}{|l|}{ Mean } & 102.91 & 102.52 & $\begin{array}{l}102.6 \\
7\end{array}$ & 100.66 & 100.89 & 99.78 & 101.04 & 100.28 & 100.08 & 100.94 & 99.46 & $\begin{array}{l}100.9 \\
8\end{array}$ \\
\hline \multicolumn{4}{|l|}{ \pm S.D. } & 1.07 & 1.08 & 1.09 & 3.30 & 3.23 & 3.05 & 1.622 & 1.61 & 1.54 & 1.35 & 0.96 & 1.32 \\
\hline \multicolumn{4}{|c|}{ \%R.S.D. } & 1.03 & 1.05 & 1.06 & 3.27 & 3.20 & 3.05 & 1.60 & 1.60 & 1.53 & 1.33 & 0.96 & 1.30 \\
\hline
\end{tabular}

Table 6: Results obtained for determination of MEB and CHL in Coloverin A tablets applying standard addition technique using CLS, PCR, and PLS techniques by Method II.

Precision: For method I and II Repeatability (intraday) and intermediate precision (interday) were assessed using three concentrations and three replicates of each concentration over 3 consecutive days. The results obtained including the mean of the recovery and standard deviation are displayed in tables $(4,7$ and 8). The low RSD $(<1)$ indicated the good precision, reasonable repeatability and reflects the ruggedness of the proposed method.

\begin{tabular}{|l|l|l|l|l|l|l|}
\hline & \multicolumn{2}{|l|}{ MEB } & \multicolumn{2}{l|}{ CHL } \\
\hline Conc. & $43.2 \mu \mathrm{g} / \mathrm{mL}$ & $\begin{array}{l}54 \\
\mu \mathrm{g} / \mathrm{mL}\end{array}$ & $\begin{array}{l}64.8 \\
\mu \mathrm{g} / \mathrm{mL}\end{array}$ & $\begin{array}{l}1.6 \\
\mu \mathrm{g} / \mathrm{mL}\end{array}$ & $2 \mu \mathrm{g} / \mathrm{mL}$ & $\begin{array}{l}2.4 \\
\mu \mathrm{g} / \mathrm{mL}\end{array}$ \\
\hline Mean & 43.26 & 54.38 & 65.11 & 1.61 & 2.01 & 2.39 \\
\hline \%Recovery & 100.14 & 100.7 & 100.48 & 100.62 & 100.5 & 99.58 \\
\hline
\end{tabular}


Citation: Othman AA, El-Bagary RI, Elkady EF, El-Kerdawy MM (2016) Development and Validation of Spectrophotometric Methods for the Simultaneous Determination of Mebeverine Hydrochloride and Chlordiazepoxide in Bulk and in Dosage Form. Pharm Anal Acta 7: 501. doi: $10.4172 / 2153-2435.1000501$

Page 7 of 8

\begin{tabular}{|l|l|l|l|l|l|l|}
\hline \pm S.D. & 0.24 & 0.51 & 0.73 & 0.02 & 0.02 & 0.01 \\
\hline \%R.S.D. & 0.56 & 0.94 & 1.12 & 0.94 & 1.22 & 0.57 \\
\hline
\end{tabular}

4. $\quad$ Seligman MEP, Walker EF, Rosenhan DL (2000) Abnormal psychology (4th edn.) New York: W.W. Norton \& Company, Inc.

5. Siddappa K, Mallikarjun M, Reddy T, Tambe M (2008) Simple and Sensitive Extractive Spectrophotometeric Method for the Assay of Mebeverine Hydrochloride in Pure and Pharmaceutical Formulations. J Chin Chem Soc 55: 1062-1068.

Table 7: Results for determination of inter-day assay for MEB and CHL in bulk powder by Method I.

\begin{tabular}{|l|l|l|l|l|l|l|}
\hline \multirow{2}{*}{ Item } & \multicolumn{2}{|l|}{ MEB } & \multicolumn{2}{l|}{ CHL } \\
\cline { 2 - 7 } & CLS & PCR & PLS & CLS & PCR & PLS \\
\hline $\begin{array}{l}\text { Intraday } \\
\text { (\%R.S.D.) } \\
\begin{array}{l}\text { For binary } \\
\text { mixture }\end{array}\end{array}$ & $\begin{array}{l}(0.16-0 \\
.59)\end{array}$ & $\begin{array}{l}(0.17-0 . \\
60)\end{array}$ & $\begin{array}{l}(0.16-0.6 \\
0)\end{array}$ & $\begin{array}{l}(0.09-0.84 \\
)\end{array}$ & $0.25-1.02)$ & $\begin{array}{l}(0.26-0 . \\
85)\end{array}$ \\
\hline $\begin{array}{l}\text { Interday } \\
\text { (\%R.S.D.) } \\
\text { For binary } \\
\text { mixture }\end{array}$ & $\begin{array}{l}(0.43-0 \\
.70)\end{array}$ & $\begin{array}{l}(0.40-0 . \\
68)\end{array}$ & $\begin{array}{l}(0.40-0.6 \\
9)\end{array}$ & $(0.73-1.29$ & $(1.11-1.28$ & $\begin{array}{l}(1.17-1 . \\
86)\end{array}$ \\
\hline
\end{tabular}

6. Sreedhar K, Sastry CSP, Narayana Reddy M, Sankar DG (1997). Spectrophotometric determination of mebeverine hydrochloride. Microchim Acta 126: 131-135.

7. Derayea SMS (2014) An application of eosin Y for the selective spectrophotometric and spectrofluorimetric determination of mebeverine hydrochloride. Anal Methods 6: 2270-2275.

8. Naveed S, Waheed N, Nazeer S, Rehman H (2015) Method development of mebeverine hydrochloride by using UV spectrophotometric method. Int J Appl Sci-Res and Rev 2: 1-5.

9. Siddiqui FA, Sher N, Hasan N, Shafi N, Shamshad H, et al. (2014) Spectrophotometric Multivariate Calibration Approach: Application in Quantitative Determination of Mebeverine in Bulk Drug and Pharmaceutical Formulations. World Appl Sci J 32: 1418-1422.

Table 8: Intraday and Interday results for determination of MEB and CHL by Method II.

Selectivity: It was found that MEB and CHL can be determined simultaneously either in their laboratory prepared mixtures or in their co formulated tablets as shown in table (2) with adequate accuracy and precision. The UV scans of the dosage form overlay those of the laboratory prepared mixtures indicating absence of interference due to excipients in the dosage form. The results displayed in tables (2 and 3) demonstrate good recoveries and absence of interference from other materials in pharmaceutical dosage forms (Coloverin A tablets) and in laboratory prepared mixtures, confirm the selectivity of the methods.

Limit of detection and limit of quantification: According to the $\mathrm{ICH}$ recommendations, [49] the approach based on the SD of the response and the slope was used for determining the limit of detection and limit of quantification, using the equations:

$\mathrm{LOD}=3.3 \mathrm{xSD} /$ slope, $\mathrm{LOQ}=10 \mathrm{xSD} /$ slope

\section{Conclusion}

The proposed methods have the advantages of simplicity, precision, accuracy and convenience for the quantization of MEB and CHL in their combined dosage form. The methods were validated for the drug substances and drug product by means of the analysis of typical performance characteristics such as robustness, selectivity, linearity, accuracy, precision, and system suitability, according to ICH guidelines. Results showed that the developed methods can be applied to a routine analysis, quality control of the cited drugs in ordinary laboratories.

\section{References}

1. Schaffstein W, Paanijel M, Luttecke K (1990) Comparative safety and efficacy of trimebutine verses mebeverine in the treatment of irritable bowel syndrome. Curr Ther Res 47:136-145.

2. Connel AM (1965) Physiological and clinical assessment of the effect of the musculotropic agent mebeverine on the human colon. Br Med J 2: 848-851.

3. Linder A, Selzer H, Classen V, Gans P, Offringa OR, et al. (1963) Pharmacological properties of mebeverine, a smooth muscle relaxant. Arch Inter Pharmacodyn 145: 378-395.

10. Elazazy MS, Elmasry MS, Hassan WS (2012) Conductometric and Spectroscopic Determination of Mebeverine Hydrochloride and the Solubility Products of its Ion Recognition Species. Int J Electrochem Sci 7: 9781-9794.

11. Arayne MS, Sultana N, Siddiqui FA (2005) A new RPHPLC method for analysis of mebeverine hydrochloride in raw materials and tablets. Pak J Pharm Sci 18:11-14.

12. Schutter J, Croo F, Weken G, Bossche W, Moerloose P (1985) Stability study and quantitative determination of mebeverine hydrochloride in tablets by means of reversed-phase high performance liquid chromatography. Chromatographia 20: 185-192.

13. Al-Deeb O, Al-Hadiya BM, Foda NH (1997) Quantitative analysis of mebeverine in dosage forms by HPLC. Chromatographia 44: 427-430.

14. Adib N, Souri E, Neghaban AA (2012) Validated stability indicating HPLC method for the determination of mebeverine in the presence of its degradation products: Kinetics study of its degradation in oxidative condition. Res Pharm Sci 7: 395.

15. Souri E, Negahban A A, Adib N (2014) A stability indicating HPLC method for determination of mebeverine in the presence of its degradation products and kinetic study of its degradation in oxidative condition. Res Pharm Sci 9: 199-206.

16. Al-Angary AA, Khidr SH, Abd-Elhady SS, Bayomi MA, Mahrous GM (1992) Sensitive High-Performance Liquid Chromatographic Determination of Mebeverine in Plasma Using Fluorescence Detection. Anal Lett 25: 1251-1260.

17. Radwan MA, Abdine HH, Aboul-Enein HY (2006) A validated chiral HPLC method for the determination of mebeverine $\mathrm{HCl}$ enantiomers in pharmaceutical dosage forms and spiked rat plasma. Biomed Chromatogr $20: 211-216$.

18. Hatami M, Farhadi K, Tukmechi A (2012) Fiber-based liquid-phase micro-extraction of mebeverine enantiomers followed by chiral highperformance liquid chromatography analysis and its application to pharmacokinetics study in rat plasma. Chirality 24: 634-639.

19. Dickinson RG, Baker PV, Franklin ME, Hooper WD (1991) Facile hydrolysis of mebeverine in vitro and in vivo: negligible circulating concentrations of the drug after oral administration. J Pharm Sci 80: 952-957.

20. Pinkston JD, Venkatramani CJ, Tulich LJ, Bowling DJ, Wehmeyer KR (1993) Evaluation of capillary supercritical fluid chromatography with mass spectrometric detection for the analysis of a drug (mebeverine) in a dog plasma matrix. J Chromatogr 622: 209-214.

21. Kothapelly R, Nalluri LP, Gaddam V, Rachawar NK, Akuthota AK (2014) UV spectrophotometric method development and validation for the simultaneous quantitative estimation of mebeverine hydrochloride and Chlordiazepoxide in capsules. Int J Pharm Pharm Sci $6: 345-349$.

22. Rajesh T, Lakshmi Prasanna N, Ashok Kumar A (2014) Simultaneous quantitative estimation of mebeverine hydrochloride and 
Citation: Othman AA, El-Bagary RI, Elkady EF, El-Kerdawy MM (2016) Development and Validation of Spectrophotometric Methods for the Simultaneous Determination of Mebeverine Hydrochloride and Chlordiazepoxide in Bulk and in Dosage Form. Pharm Anal Acta 7: 501. doi: 10.4172/2153-2435.1000501

Page 8 of 8

Chlordiazepoxide in capsules using spectrophotometry. International journal of pharmacy and pharmaceutical sciences 6: 96-100.

23. Patel DJ, Patel JK, Patel VP (2011) Simultaneous spectrophotometric estimation of mebeverine hydrochloride and chlordiazepoxide in tablet dosage form. Inventi rapid: Pharmana and Qual Assur 2.

24. Lotfy HM, Fayez YM, Michael AM, Nessim CK (2016) Simultaneous determination of mebeverine hydrochloride and chlordiazepoxide in their binary mixture using novel univariate spectrophotometric methods via different manipulation pathways. Spectrochim Acta A Mol Biomol Spectrosc 155: 11-20.

25. Heneedak H M, Ismail S, Mostafa S, El-Sadek M (2014) A Stabilityindicating HPLC Method for the Simultaneous Determination of Mebeverine Hydrochloride and Chlordiazepoxide in Commercial Tablets. Curr Anal Chem 10: 565-573.

26. Haggag RS, Shaalan RA, Belal TS (2010) Validated HPLC determination of the two fixed dose combinations (chlordiazepoxide hydrochloride and mebeverine hydrochloride; carvedilol and hydrochlorothiazide) in their tablets. J AOAC Int 93: 1192-1200.

27. Kekare MB, Choukekar MP, Vaidya VV, Sing GR (2008) Simultaneous RP-HPLC Determination Of Mebeverine $\mathrm{HCl}$ And Chlorodiazepoxide In Pharmaceutical Preparations. Analytical Chemistry: Indian J 7: 602-605.

28. El-Shaheny RN, Belal FF (2015) Simultaneous RP-HPLC Determination Of Chlordiazepoxide And Mebeverine $\mathrm{HCl}$ In the presence of their degradation products and impurities. J Chem 2015: 1-9.

29. Sujana K, Hamuthal MZV, Murthy VSN Shravani N (2015) A Novel Validated Analytical Method Development for the Binary Mixture of Mebeverine and Chlordiazepoxide in Pharmaceutical Formulation and its Application to Stress Studies. Pharm Anal Acta 6: 324-329.

30. Soentjens-Werts V, Dubois JG, Atassi G, Hanocq M (1994) Highperformance liquid chromatographic determination of chlordiazepoxide, its metabolises and oxaziridines generated after UV irradiation. J Chromatogr A 662: 255-262.

31. Roberts SE, Delaney MF (1984) Determination of chlordiazepoxide, its hydrochloride and related impurities in pharmaceutical formulations by reversed-phase high-performance liquid chromatography. J Chromatogr 283: 265-272.

32. Greizerstein HB, Mclaughlin IG (1980) The High-Pressure Liquid Chromatographic Determination of Chlordiazepoxide and Its NDemethyl Metabolite in Mouse Brain. J Liq Chromatogr 3:1023-1030.

33. Strojny N, Puglisi CV, de Silva JAF (1978) Determination of Chlordiazepoxide and Its Metabolites in Plasma by High Pressure Liquid Chromatography. Anal Lett 11: 135-160.

34. Song D, Zhang S, Kohlhof K (1994) Determination of chlordiazepoxide in mouse plasma by gas chromatography-negative-ion chemical ionization mass spectrometry. J Chromatogr B Biomed Appl 660: 95-101.

35. Sun SR (1978) Quantitative determination of chlordiazepoxide and its metabolites in serum by fluorescence TLC-densitometry. J Pharm Sci 67: 639-641.
36. Gupta SP, Upmanyu N, Garg G (2012) Development and validation of spectrophotometric, HPTLC and HPLC methods for the determination of Imipramine and Chlordiazepoxide in pharmaceutical dosage forms. J Der Pharmacia Sinica 3: 185-192.

37. Patel S, Patel NJ (2009) Spectrophotometric and chromatographic simultaneous estimation of amitriptyline hydrochloride and chlordiazepoxide in tablet dosage form. Indian J Pharm Sci 71: 472-476.

38. Patel SK, Patel NJ (2009) Simultaneous RP-HPLC Estimation of Trifluoperazine Hydrochloride and Chlordiazepoxide in Tablet Dosage Forms. Indian J Pharm Sci 71: 545-547.

39. Patel S, Patel NJ, Patel SA (2009) Simultaneous Spectrophotometric Estimation of Imipramine Hydrochloride and Chlordiazepoxide in Tablets. Indian J Pharm Sci 71: 468-472.

40. Venisetty RK, Kamarapu SK (2013) RP-HPLC Method development and validation for simultaneous estimation of clidinium bromide, chlordiazapoxide and dicyclomine hydrochloride in bulk and combined tablet dosage forms. Int J Ad Biomed Pharm Res 2: 35-40.

41. Patel AH, Patel JK, Patel KN, Ragput GC, Rajgor NB (2010) Development and validation of derivative spectrophotometric method for simultaneous estimation of domperidone and rabeprazole sodium in bulk and dosage forms. Int J Pharm Biol Res 1: 1-5.

42. Khajehsharifi H, Eskandari Z, Asadipour A ( 2010) Application of some chemometric methods in conventional and derivative spectrophotometric analysis of acetaminophen and ascorbic acid. Drug Test Anal 2: 162-167.

43. Hegazy MA, El-Ghobashy MR, Yehia AM, Mostafa AA (2009) Simultaneous determination of metformin hydrochloride and pioglitazone hydrochloride in binary mixture and in their ternary mixture with pioglitazone acid degradate using spectrophotometric and chemometric methods. Drug Test Anal 1: 339-349.

44. Ni Y, Gong X (1997) Simultaneous spectrophotometric determination of mixtures of food colorants. Anal Chim Acta 354: 163-171.

45. El-Gindy A (2005) HPLC and chemometric assisted spectrophotometric methods for simultaneous determination of diprophylline, phenobarbitone and papaverine hydrochloride. Il Farmaco 60: 745-753.

46. Abbaspour A, Mirzajani R (2005) Simultaneous determination of phenytoin,barbital and caffeine in pharmaceuticals by absorption (zeroorder) UV spectra and first-order derivative spectra multivariate calibration methods. J Pharm Biomed Anal 38: 420-427.

47. Blanco M, Coello J, Gonzalez F, Iturriaga H, Maspoch S (1993) Spectrophotometric analysis of a pharmaceutical preparation by principal component regression. J Pharm Sci 82: 834-837.

48. Kramer R (1998) Chemometric Techniques for Quantitative Analysis, Marcel Dekker Inc.: New York.

49. (2005) ICH, Validation of analytical Procedures: Text and methodology Q2(R1). International Conference on Harmonization(ICH), Geneva. 